\title{
Concrete quality assessment before building structures submitting to environmental exposure conditions
}

\author{
Evaluación de la calidad del hormigón antes de construir estructuras sometida a condiciones \\ medioambientales de exposición
}

\author{
Abel Castañeda (Main and Corresponding Author) \\ Centro Nacional de Investigaciones Científicas. Dirección de Medio Ambiente \\ Avenida 25 y 158. Apartado Postal 6414, La Habana (Cuba) \\ abel.castaneda@cnic.edu.cu
}

Juan José Howland Albear

Facultad de Ingeniería Civil. Universidad Tecnológica de La Habana CUJAE

Apartado postal 19390 (Cuba)

jhalbear@civil.cujae.edu.cu

\section{Francisco Corvo}

Universidad Autónoma de Campeche.

Centro de Investigaciones de Corrosión

Apartado Postal 24030 (México)

frecorvo@uacam.mx

\section{Rigoberto Marrero}

Facultad de Ingeniería Química. Universidad Tecnológica de La Habana CUJAE

Apartado postal 19390 (Cuba)

rigo@quimica.cujae.edu.cu

Manuscript Code: 653

Date of Acceptance/Reception: 30.11.2017/18.06.2016

DOI: $10.7764 /$ RDLC.16.3.374

\begin{abstract}
A study on concrete quality assessment before building structures submitting to environmental exposure conditions was carried out. It was necessary to determine the ultrasonic velocity pulse, compressive strength and percentage of effective capillary porosity values in concretes probes of water/cement ratio $0.4,0.5$ and 0.6.The results allowed to demonstrate how from relationship between compressive strength and percentage of effective capillary porosity, as well as, from relationship between capillary coefficient absorption and percentage of effective capillary porosity, durability requirements were obtained. Durability requirements were: Critical value of percentage of effective capillary porosity from which the concrete permeability increased. Critical value of percentage of effective capillary porosity from which, compressive strength decreased. Ultrasonic pulse velocity and compressive strength tests by itself were not enough to concrete quality assessment. Results using the visual observation were confirmed, in the reinforced concrete probes exposed to corrosivity categories of the atmospheres very high (C5) and extreme (CX) in a tropical coastal climates during three years, as well as by scanning electron microscopy tests in small samples of hardened cement paste for the three water/cement ratios.
\end{abstract}

Key words: Concrete, quality, durability, capillary, porosity.

Resumen

Un estudio basado en la evaluación de la calidad del hormigón antes de construir estructuras sometidas a condiciones medioambientales de exposición fue ejecutado. Fue necesario determinar los valores de velocidad de pulso ultrasónico, resistencia a la compresión y el porcentaje de porosidad capilar efectivo en probetas de hormigón de relaciones agua/cemento 0.4, 0.5 y 0.6. Los resultados permitieron demostrar cómo a partir de la relación entre la resistencia a la compresión y el porcentaje de porosidad capilar efectivo, así como, a partir de la relación entre el coeficiente de absorción capilar y el porcentaje de porosidad capilar efectivo, criterios por durabilidad fueron obtenidos. Los criterios durabilidad fueron: Valor crítico de porcentaje de porosidad capilar efectivo a partir del cual la permeabilidad en el hormigón se incrementó. Valor crítico de porcentaje de porosidad capilar efectivo a partir del cual la resistencia a la compresión disminuyó. Los ensayos de velocidad de pulso ultrasónico y resistencia a la compresión por sí solo no fueron suficientes en la evaluación de la calidad del hormigón. Los resultados fueron confirmados usando la observación visual en probetas de hormigón armado expuestas a categorías de corrosividad de la atmósfera de muy elevada (C5) y extrema (CX) en un clima tropical costero durante tres años, así como por ensayos de microscopía electrónica de barrido en pequeñas muestras de pasta de cemento endurecida para las tres relaciones agua/cemento. 
The concrete quality assessment, have been carried out in diagnostic studies in situ from different physico-chemical and mechanical tests, mainly when reinforced concrete structures present a level of deterioration very advanced, due to atmospheric corrosion of steel reinforced concrete (Fernández, Martín, Rey, Pares, García, Lago, \& Denis, 2005; Bermúdez \& Gutiérrez, 2007; Castañeda, Rivero, \& Corvo, 2012; Castro-Borges, Torres-Acosta, Balancán-Zapata, \& López-González, 2012). This trend has been widespread in Cuba and Latin America, principally in tropical coastal climate zones of high constructive potential. Reinforced concrete structures are exposed to corrosivity categories of the atmospheres high (C4), very high (C5) and extreme (CX) according to specification required in ISO 9223 standard (International Standard ISO 9223, 2012).

Compressive strength and ultrasonic pulse velocity has been the tests most used to assess the concrete quality in situ. The results obtained from diagnostic studies, have served to recover the durability and the useful life of the reinforced concrete structures (Medeiros \& Helene, 2009; Ozbek, 2013; Chen, Wu, \& Zhou, 2013). As is well known, the diagnostic studies and the latter ones repair works are very expensive. Therefore, to deepen in the concrete quality assessment before building structures submitting to environmental exposure conditions is very necessary.

Several researchers have considered that ultrasonic pulse velocity is a fundamental parameter to confirm the concrete quality as an indication of its compactness and durability (Acebes, 2011; Benmeddour, 2012; Petro \& Kim, 2012; Shariq, Prasad, \& Masood, 2013).

On the other hand, researches works have been found where the concrete quality was assessed before building structures submitting to environmental exposure conditions. Besides the compressive strength and ultrasonic pulse velocity; percentage of effective capillary porosity determination has been taking into account as direct indicator of the concrete permeability (Castañeda, Corvo, Howland, \& Pérez, 2013). Nevertheless, deterioration problems in the reinforced concrete structures due to atmospheric corrosion of steel reinforced concrete it keeps, mainly in tropical coastal climate zones near from the sea without shielding conditions (Castañeda et al., 2012).

Everything seems to indicate that compressive strength, ultrasonic pulse velocity and percentage of effective capillary porosity determination tests are not enough to assess the concrete quality before building structures submitting to environmental exposure conditions to increase the durability and useful life. The relationship between compressive strength and percentage of effective capillary porosity, as well as, between capillary coefficient absorption and percentage of effective capillary porosity, could be a necessary and sufficient tool.

The compressive strength of concrete is influenced by the volume of all voids in the concrete (entrapped air, capillary pores, gel pores and entrained air). Statistical regressions have been proposed to express the relationship between compressive strength and porosity (Table 1).

\begin{tabular}{|c|c|c|}
\hline No. & Regressions & Mathematical Law \\
\hline 1 & $R_{b k}=a-b P_{t}$ & $\begin{array}{l}\text { Hasselmann } \\
\text { Linear }\end{array}$ \\
\hline 2 & $R_{b k}=a e^{\left(-x / P_{t}\right)}$ & $\begin{array}{l}\text { Ryshkevitch } \\
\text { Exponential }\end{array}$ \\
\hline 3 & $R_{b k}=a\left(P_{t}\right)^{b}$ & $\begin{array}{l}\text { Balshin } \\
\text { Power }\end{array}$ \\
\hline 4 & $R_{b k}=a-P_{0} \ln \left(P_{t}\right)$ & $\begin{array}{l}\text { Schiller } \\
\text { Logarithmical }\end{array}$ \\
\hline
\end{tabular}

Nevertheless, few reports have been found where, compressive strength $\left(R_{b k}\right)$ and percentage of total porosity in the concrete and mortars $\left(P_{t}\right)$ have been correlated from different statistical regressions (Kearsley, \& Wainwrightb, 2002; Lian, Zhuge, \& Beecham, 2011).

The compressive strength on total porosity dependence for porous concretes was analyzed empirically using the four statistical regressions. The suitability of existing regression for porous concretes was assessed. A new model was proposed. The new model, which was derived from Griffith's theory, presented a better agreement with the 
experimental data for porous concretes. It was demonstrated that proposed model, could provide a better compressive strength prediction in porous concretes (Lian, Zhuge, \& Beecham, 2011).

On the others hand, the four regressions to express the relationship between compressive strength and porosity of porous solids were used. The optimum values of the constant terms and the regression that best expressed the relationship between compressive strength and total porosity for its set of Portland cement pastes were determined. The same procedure was used to determine whether these regressions could be applied to express the relationship between compressive strength and porosity in foamed concrete mixtures with high ash contents. The results indicated that for the 1-year, any one of the four regressions can be fitted; resulting in a relatively strong relationship between the compressive strength and the porosity of the foamed concrete. Linear regression (Hasselmann) fit results better. Nevertheless, results of other authors were best fit to an exponential function (Ryshkevitch). Porosity of the foamed concrete was determined using the Vacuum Saturation Apparatus (Kearsley \& Wainwrightb, 2002).

No reports have been found where from relationship between compressive strength and percentage of effective capillary porosity using the four regressions (Table 1); durability requirements can be obtained to concrete quality assessment before building structures submitting to environmental exposure conditions. Percentage of effective capillary porosity values are obtained from capillary flow of water absorption measurement (Fagerlung, 1986).

The influence of the atmospheric environment on different concrete quality was the main study of the CYTED project DURACON, conducted throughout 11 Ibero-American countries (Argentina, Bolivia, Brazil, Chile, Colombia, Costa Rica, Mexico, Spain, Uruguay, Portugal and Venezuela).The concrete quality was assessed from compressive strength, percentage of effective capillary porosity, resistance to penetration of water flow and capillary coefficient absorption using the methodology established by Fagerlund. The relationship between compressive strength and percentage of effective capillary porosity, as well as, between capillary coefficient absorption and percentage of effective capillary porosity to assess the concrete quality was not taken account (Trocónis \& Duracon Collaboration, 2006; Trocónis et al., 2007).

Therefore, demonstrate how from relationship between compressive strength and percentage of effective capillary porosity, as well as, from relationship between capillary coefficient absorption and percentage of effective capillary porosity is very necessary to concrete quality assessment before building structures submitting to environmental exposure conditions. This will allow obtaining durability requirements. Moreover, useful life of the reinforced concrete structures would be increased. Thus, maintenance and repairing works decrease on time.

The results obtained were confirmed through visual observation in the reinforced concrete probes exposed to corrosivity categories of the atmospheres very high (C5) and extreme (CX) in the tropical coastal climate of Havana City, Cuba, without shielding conditions, as well as, using the observation in small samples of hardened cement paste carried out by Scanning Electronic Microscopy.

Materials and methods

\section{Concrete probes elaboration}

Six concrete probes with the straight rectangular prisms form with dimensions of $200 \times 200 \times 200 \mathrm{~mm}$, two for each water/cement ratio $0.4,0.5$ and 0.6 were elaborated. On the others hands, another thirty-six probes in the cylindrical form of $300 \times 150 \mathrm{~mm}$ of diameter $(\varnothing)$ and height $(\mathrm{h})$, twelve for each water/cement ratio were also elaborated.

Concrete used in the probes elaboration was dosed taking into account the achievement of a minimum percentage of voids between the fine and coarse aggregates. Concrete mix composition was: Ordinary Portland cement P-350: $365 \mathrm{~kg}$; Havana calcareous sand: $750 \mathrm{~kg}$ (modulus of fineness 3.62, absorption percent 3.3); Hard limestone gravel (coarse aggregate, triturability index 9.6, absorption percent 1.5): $1030 \mathrm{~kg}$ with a nominal size of $19 \mathrm{~mm}$. A superplasticizer admixture to obtain a concrete mix with fluid consistency and assure a good compaction was used (Table 2). For removal of the entrapped air in the mixes, compaction processes using a vibrating table on each cubic and cylindrical carbon steel mold was carried out. The mixtures were kept in the molds during 24 hours.

Table 2.Water and admixture volumes used in the concrete probes elaboration. Source:
elaboration, 2013.
\begin{tabular}{cccc} 
Concrete & volume of \\
settling & water & Admixture \\
W/c & $(\mathrm{cm})$ & (L) & $(\%)$ \\
\hline
\end{tabular}




\begin{tabular}{llll}
\hline 0.4 & 15 & 148 & 1.7 \\
0.5 & 17 & 186 & 1.5 \\
0.6 & 18 & 222 & 1.0 \\
\hline
\end{tabular}

Corresponding fits for each dosage of all materials to ensure $1 \mathrm{~m}^{3}$ net volume of concrete were carried out. When the mixture was designed aggregates were weighed until constant weight. Therefore, each dosage was different at change water/cement ratio.

Concrete probes elaborated, in the two forms (cubic and cylindrical), were submitted to water immersion curing process during 28 days. The water temperature was $\left(23^{\circ} \mathrm{C} \pm 2\right)$ (NC ISO-1920-3, 2010).

\section{Compressive strength determination}

Twelve values of compressive strength $\left(R_{b k} M p a\right)$ in the cylindrical probes for the three water/cement ratio were obtained. A Russian test machine of maximum axial compression force of $2000 \mathrm{KN}$ to obtaining the thirty-six values was used. Thirty-six values were plotted with the percentage of effective capillary porosity for the three water/ cement ratio (NC 724, 2015).

\section{Ultrasonic pulse velocity determination}

Twelve values of ultrasonic pulse velocity $\left(U P V \mathrm{~m} \mathrm{~s}^{-1}\right)$ in three concrete probes with the straight rectangular form for each water/cement ratio were obtained from the transmission direct method. This method is based in the placement of transducers on opposite sides of the probes or elements in situ (Figure 1). Values between each opposite side were obtained (NC 231, 2002).

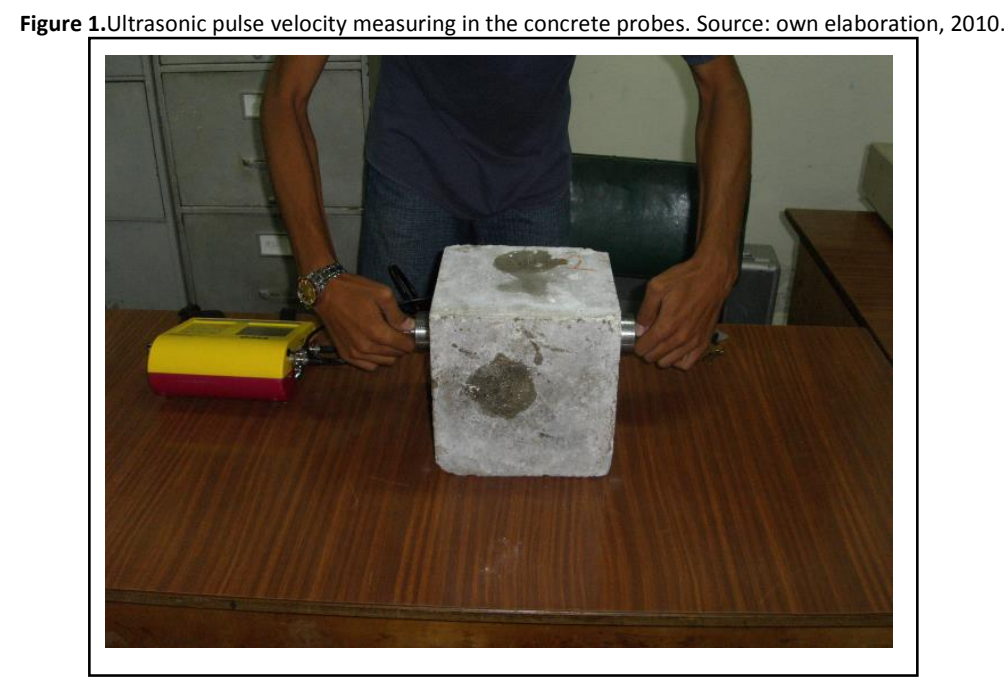

Grease(petrolatum) of minimum thickness to enable a good coupling and electric wave transmission between the transducers was necessary to apply (NC 231, 2002). An equipment of TICO PROCEQ TESTING INSTRUMENT mark USmade with a measurement range from $15 \mu \mathrm{s}$ up to $6550 \mu \mathrm{s}\left(10^{-6} \mathrm{~s}\right)$ with abandwidthof $54 \mathrm{~Hz}$ was used (Figure 1$)$. Calibration from bars concrete references before the execution of measurements equipment was carried out.

Average values to classify the concrete quality for the three water/cement ratios were used. Criteria for the concrete quality assessment depending on ultrasonic pulse velocity values $\left(\mathrm{m} \mathrm{s}^{-1}\right)$ exist in the DURAR net of CyTED program (Trocónis, 1997).

\section{Concrete permeability determination}

\section{Percentage of effective capillary porosity determination by water absorption}

Twelve concrete samples in cylindrical form for each water/cement ratio for a total of thirty-six were obtained to determine the percentages of effective capillary porosity using Göran Fagerlund methodology (Fagerlung, 1986). It is necessary first to obtain two key parameters such as: penetration resistance to capillary flow of water absorption $\left(m s \mathrm{~m}^{-2}\right)$ and capillary coefficient absorption $\left(\mathrm{k} \mathrm{kg} \mathrm{m}^{-2} \mathrm{~s}^{-\frac{1}{2}}\right)$. 
A Chinese machine of core extraction was used to extract a core in cylindrical form of the other three concrete probes with straight rectangular prisms for three water/cement ratio. Twelve cylindrical samples of $62 \mathrm{~mm}$ of diameter and $20 \mathrm{~mm}$ of thickness for each water/cement ratio were obtained. Cylindrical concrete cores were cut in saw tungsten CUSHION CUT mark US-made. The twelve concrete samples cut for each water/cement ratio were submitted later to drying process until constant weight at a temperature of $50^{\circ} \mathrm{C}$. A Germany laboratory oven UNB-400 of MENMERT mark was used. The drying process is carried out for the total evaporated water loss located in the capillary pores of concrete.

Concrete samples removed from the oven were submitted to cooling process inside desiccators. Curved lateral zones were coated with paraffin for capillary flow of water absorption takes place only by the circular area directly exposed to water. The initial weights $\left(W_{0} \mathrm{~kg}\right)$ at 36 cylindrical concrete samples (12 for each water/cement ratio) were carried out. Swedish analytical balance hydrostatic of METLER marks of maximum weight $8100 \mathrm{~g}$ and $1 \mathrm{~g}$ of precision was used.

Twelve concrete samples for each water/cement ratio were place on plastic supports inside a plastic cuvette. Water level does not exceed $5 \mathrm{~mm}$ of height above the bottom surface of each concrete samples (Figure 2). A test tube filled with water in inverted position was placed. Thus the water level in the cuvette at $5 \mathrm{mmis}$ kept (Figure 2). The room temperature was $20^{\circ} \mathrm{C}$.

Figure 2.Experimental system to determine the percentages of effective capillary porosity using Göran Fagerlund methodology. Source: own elaboration, 2015.

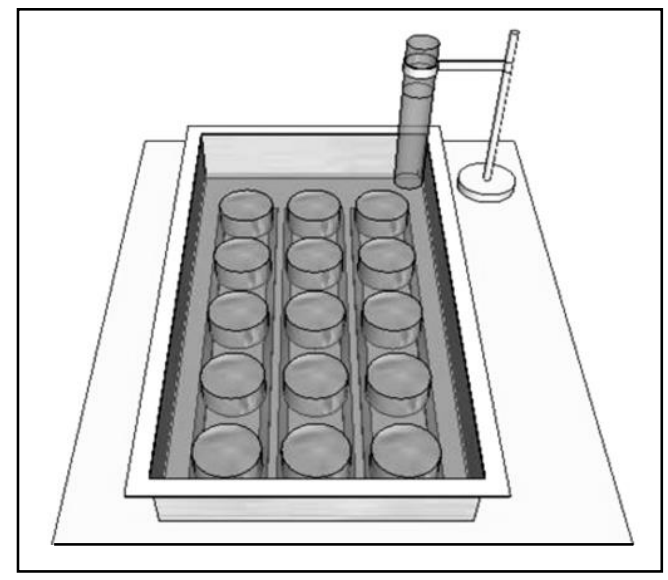

The final weight due to water absorption in concrete sample $\left(W_{t} \mathrm{~kg}\right)$ after placed on plastic support in the same balance was carried out at time of 5, 10, 15, 30 minutes, 1, 2, 3, 4, 6, 24 and48 hours verifying that time the concrete samples reached the maximum saturation state of water, that is to say, the time required $(t)$ so that water flow ascend toward the top side of the concrete sample. This time values $(t s)$,are obtained numerically through intercept point between the positive slope line and the straight line, that is to say, where the water gain begins to keep constant in the capillary absorption curves. The values are used to calculate the resistance penetration to capillary flow of water absorption ( $m s \mathrm{~m}^{-2}$ ) according to expression:

$$
\mathrm{m}=\frac{\mathrm{t}}{\mathrm{z}^{2}}\left(\mathrm{~s} \mathrm{~m}^{-2}\right)
$$

z: Sample thickness.

Göran Fagerlund methodology establishes that capillary coefficient absorption $\left(k \mathrm{~kg} \mathrm{~m}^{-2} \mathrm{~s}^{-\frac{1}{2}}\right)$ can be calculated from the positive slope line of the capillary absorption water curve $\left(W_{t}-W_{0}\right) / A v s \sqrt{t}\left(A=0.00302 \mathrm{~m}^{2}\right.$ is the circular area of the cylindrical sample in contact with water in the cuvette).Twelve percentages of effective capillary porosity $(\varepsilon)$ values for each water/cement ratio were calculated according to expression:

$$
\varepsilon=\frac{\mathrm{k} \sqrt{\mathrm{m}}}{1000}(\%)
$$

The percentages of effective capillary porosity values were classified according to specifications established in the DURAR net of CYTED program (Trocónis, 1997). 


\section{Scanning Electron Microscopy (SEM)}

Scanning electron microscopy tests were carried out in small samples of hardened cement paste for each water/cement ratio from concrete sample in cylindrical form. The small samples without polishing were introducing into the microscope camera. An environmental scanning electron microscope of secondary electron PHILIPS XL 30 ESEM mark of Dutch made was used.

First, the small samples of hardened cement paste were dried using a manual desiccator. The air temperature was $50^{\circ} \mathrm{C}$. The drying process was carried out for the total evaporated water loss located in the capillary pores of concrete. Small samples were submitted to cooling process inside desiccator.

Coating equipment SPI MODULE SPUTTER COATER mark of US-made that allowed covering the small samples of a metallic gold film on the upper side was used for a better electronic scanning.

\section{Results and discussion}

\section{Ultrasonic pulse velocity analyses}

Concrete quality assessment before building structures submitting to environmental exposure conditions was first analyzed from ultrasonic pulse velocity values (UPV). This parameter decreased when water/cement ratio it increased, as expected. Concretes for the three water/cement ratio should have an adequate quality from average values of ultrasonic pulse velocity (UPVa $>3001 \mathrm{~m} \mathrm{~s}^{-1}$ ), that is to say, high durability to resist the environmental exposure conditions according to classification ranges required in the DURAR net of CyTED program (Figure 3). Ultrasonic pulse analyzed was not taken account in the CyTED project DURACON (Trocónis \& Duracon Collaboration, 2006; Trocónis et al., 2007).

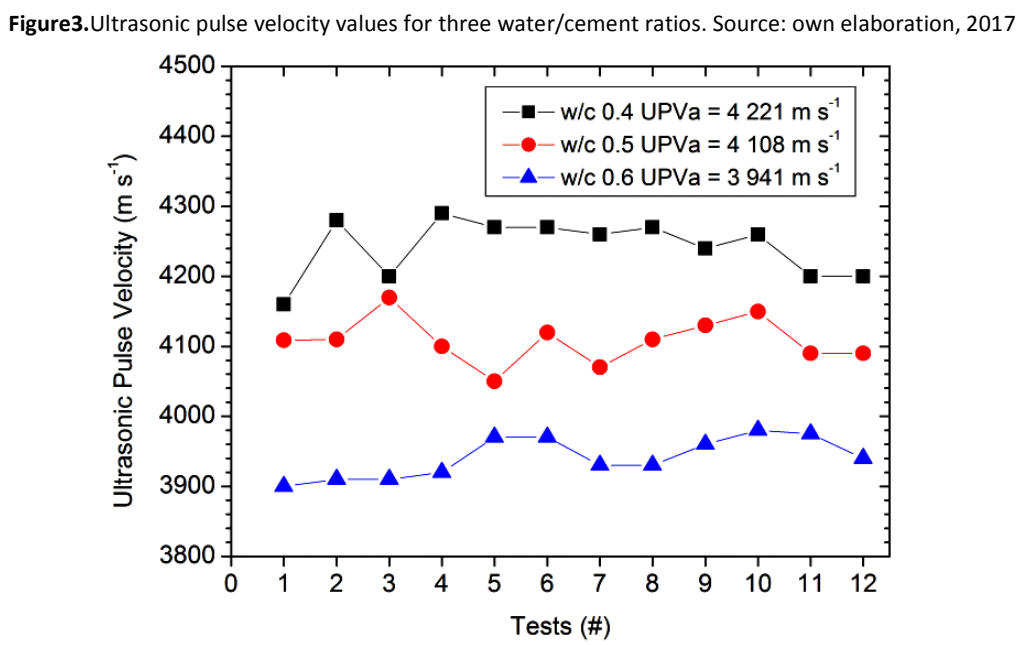

Water/cement ratios 0.5 and 0.6 correspond to design conditions most commonly used in building of the reinforced concrete structures exposed to tropical coastal climate of Cuba in coastal zones of high constructive potential.

This result indicates concretes with a good homogeneity, attribute that defines the regular distribution of components throughout the concrete mass of uniform structure.

\section{Capillary water absorption analyses}

Average capillary water absorption curve obtained from average of twelve values of $\left(W_{t}-W_{0}\right) / A$ vs $\sqrt{t}$ is observed (Figure 4). 


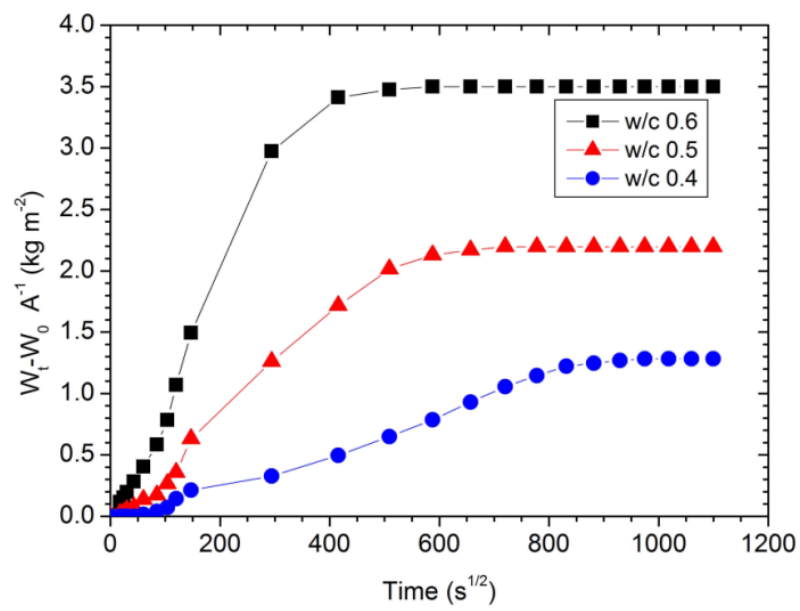

A high positive slope representative of the capillary water absorption in the concrete is increased with the water/cement ratio. Concretes with the water/cement ratios 0.5 and 0.6 reached very fast the time required $(t)$ so that water flow ascend toward the top side of the concrete sample. This is representative of high percentage of effective capillary porosity values (Figure 4).

Higher penetration of aggressive agents such as chloride salts through capillary pores of the concrete is guaranteed to start and develop the atmospheric corrosion of steel reinforced concrete in coastal zone mainly in the concrete with water/cement ratio 0.5 and 0.6 . A high durability for the concretes with these water/cement ratio was demonstrated from ultrasonic pulse velocity values.

Twelve values of penetration resistances to capillary flow of water absorption $\left(m s \mathrm{~m}^{-2}\right)$ for the three water/cement ratio are observed (Table 3 ). Although concrete is a very heterogeneous material, variation coefficients values were small. Therefore, capillary flow of water absorption was very homogeneous in the concrete samples for the three water/cement ratio. Capillary pores could be more or less interconnected throughout the cement paste in concrete mass and with the environmental exposure conditions. As it is known, capillary pores in the concrete are those most responsible of aggressive agent's penetration towards reinforcement steel surface.

Table 3.Penetration resistance values to capillary flow of water absorption. Source: own elaboration, 2015

\begin{tabular}{cccc}
\hline & $\mathrm{w} / \mathrm{c} 0.4^{\text {Concrete }}$ & $\mathrm{w} / \mathrm{c} 0.5$ & $\mathrm{w} / \mathrm{c} 0.6^{\circ}$ \\
\cline { 2 - 4 } Samples & $\mathrm{m}$ & $\mathrm{m}$ & $\mathrm{m}$ \\
$\left(\mathrm{s} \mathrm{m}^{-2}\right)$ & $\left(\mathrm{s} \mathrm{m}^{-2}\right)$ & $\left(\mathrm{s} \mathrm{m}^{-2}\right)$ \\
\hline 1 & $1.59 \times \mathrm{E}^{09}$ & $5.25 \times \mathrm{E}^{08}$ & $3.27 \times \mathrm{E}^{08}$ \\
2 & $1.93 \times \mathrm{E}^{09}$ & $5.28 \times \mathrm{E}^{08}$ & $3.19 \times \mathrm{E}^{08}$ \\
3 & $1.83 \times \mathrm{E}^{09}$ & $6.96 \times \mathrm{E}^{08}$ & $3.84 \times \mathrm{E}^{08}$ \\
4 & $1.81 \times \mathrm{E}^{09}$ & $6.38 \times \mathrm{E}^{08}$ & $2.43 \times \mathrm{E}^{08}$ \\
5 & $2.26 \times \mathrm{E}^{09}$ & $6.37 \times \mathrm{E}^{08}$ & $3.16 \times \mathrm{E}^{08}$ \\
6 & $1.50 \times \mathrm{E}^{09}$ & $5.46 \times \mathrm{E}^{08}$ & $2.21 \times \mathrm{E}^{08}$ \\
7 & $1.93 \times \mathrm{E}^{09}$ & $7.04 \times \mathrm{E}^{08}$ & $2.43 \times \mathrm{E}^{08}$ \\
8 & $1.92 \times \mathrm{E}^{09}$ & $8.41 \times \mathrm{E}^{08}$ & $3.88 \times \mathrm{E}^{08}$ \\
9 & $1.44 \times \mathrm{E}^{09}$ & $7.85 \times \mathrm{E}^{08}$ & $3.29 \times \mathrm{E}^{08}$ \\
10 & $1.51 \times \mathrm{E}^{09}$ & $8.16 \times \mathrm{E}^{08}$ & $2.92 \times \mathrm{E}^{08}$ \\
11 & $1.46 \times \mathrm{E}^{09}$ & $5.77 \times \mathrm{E}^{08}$ & $3.90 \times \mathrm{E}^{08}$ \\
12 & $1.45 \times \mathrm{E}^{09}$ & $6.51 \times \mathrm{E}^{08}$ & $2.75 \times \mathrm{E}^{08}$ \\
Averages & $1.72 \times \mathrm{E}^{09}$ & $6.62 \times \mathrm{E}^{08}$ & $3.10 \times \mathrm{E}^{08}$ \\
S.D. & $2.70 \times \mathrm{E}^{08}$ & $1.09 \times \mathrm{E}^{08}$ & $5.81 \times \mathrm{E}^{08}$ \\
V.C (\%) & 15.6 & 16.4 & 30.7 \\
\hline
\end{tabular}


Concretes before submitting to environmental exposure condition besides to having a good homogeneity and compactness due to distribution of its elements according to ultrasonic pulse velocity values for the three water/cement ratio, a good distribution of capillary pores interconnected in the hardened cement paste throughout the concrete mass could also be expected.

Capillary water absorption in concretes is also analyzed from the relationship between capillary coefficient absorption and percentage of effective capillary porosity (Figure 5).

Using classification range demonstrated in the DURAR net of CyTED program (Trocónis, 1997), it is appreciated as the concrete of water/cement ratio 0.4 average values of the percentages of effective capillary porosity determined by capillary flow of water absorption method is less than $10 \%$, indicating a concrete with good quality and durability (Figure 5). Concrete quality of water/cement ratio 0.5 is moderate ( $10 \% \leq \varepsilon<15 \%)$. Concrete quality of water/cement ratio 0.6 is inappropriate $(\varepsilon>15 \%)$.

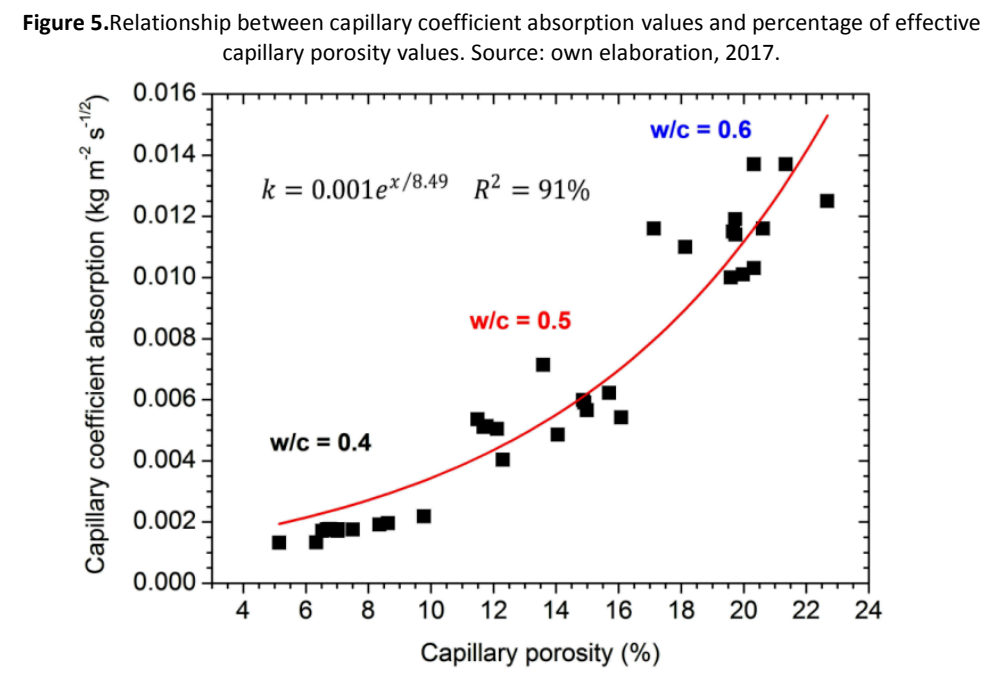

A good quality for concrete, elaborated with water/cement ratios 0.5 and 0.6 are not guaranteed. This result differs from that obtained by ultrasonic pulse velocity.

Other durability requirements from the relationship between capillary coefficient absorption and percentage of effective capillary porosity relationship are very necessary to concrete quality assessment before building structures submitting to environmental exposure conditions. An increase of capillary coefficient absorption $(k)$ in function of percentage of effective capillary porosity increases is observed as expected (Figure 5). An exponential increasing function $\left(y=a e^{x / t}\right)$ was fitted from the regression:

$$
k=a e^{x / \varepsilon}
$$

$\varepsilon$ : Critical value of percentage of effective capillary porosity from which capillary coefficient absorption $k$ it increases.

The regression obtained was (Figure 5):

$$
k=0.001 e^{x / 8.49} \quad R^{2}=91 \%
$$

According to regression fitted, from a percentage of effective capillary porosity value of $8.5 \%$, capillary coefficient absorption increases abruptly. For a percentage of effective capillary porosity value of $8.5 \%$, concrete of water/cement ratio 0.4 with capillary coefficient absorption values around $0.0028 \mathrm{~kg} \mathrm{~m}^{-2} \mathrm{~s}^{-1 / 2}$ can be obtained (Figure 5). For a percentage of effective capillary porosity value of $10 \%$ concrete of water/cement ratio 0.4 with capillary coefficient absorption values $0.0035 \mathrm{~kg} \mathrm{~m}^{-2} \mathrm{~s}^{1 / 2}$ can also be obtained. Therefore, to ensure a concrete with quality and durability adequate before building structures submitting to environmental exposure conditions in addition to having a water/cement less than or equal to 0.4 , capillary coefficient absorption values should be less than $0.0035 \mathrm{~kg} \mathrm{~m} \mathrm{~m}^{-2} \mathrm{~s}^{1 / 2}$. Therefore, as durability requirements, concretes with capillary coefficient adsorption between 0.004 and $0.008 \mathrm{~kg} \mathrm{~m}$ ${ }^{2} \mathrm{~s}^{1 / 2}(\mathrm{w} / \mathrm{c}=0.5)$, as well as between 0.010 and $0.014 \mathrm{~kg} \mathrm{~m}^{-2} \mathrm{~s}^{1 / 2}(\mathrm{w} / \mathrm{c}=0.6)$ (Figure 5), a quality and durability adequate 
should not be guaranteed for the reinforced concrete structures submitted to corrosivity categories of the atmospheres high (C4), very high (C5) and extreme (CX) in tropical coastal climates.

\section{Relationship between compressive strength and percentage of effective capillary porosity}

Compressive strength values are higher than $20 \mathrm{Mpa}$ for the three water/cement ratio (Figure 6 a), b) and d). According to establish in the DURAR net of CyTED program, durability is inadequate if compressive strength values are less than 20 Mpa.

On the others hand, the four statistical regressions between compressive strength and percentage of effective capillary porosity were fitted (Figure $6 \mathrm{a}), \mathrm{b}), \mathrm{c}$ ) and d). The best fit from regression based on exponential increasing function (Ryshkevitch) is presented (Table 4).

Figure 6.Behavior between compressive strength values and percentage of effective capillary porosity values.Source: Own elaboration, 2017.
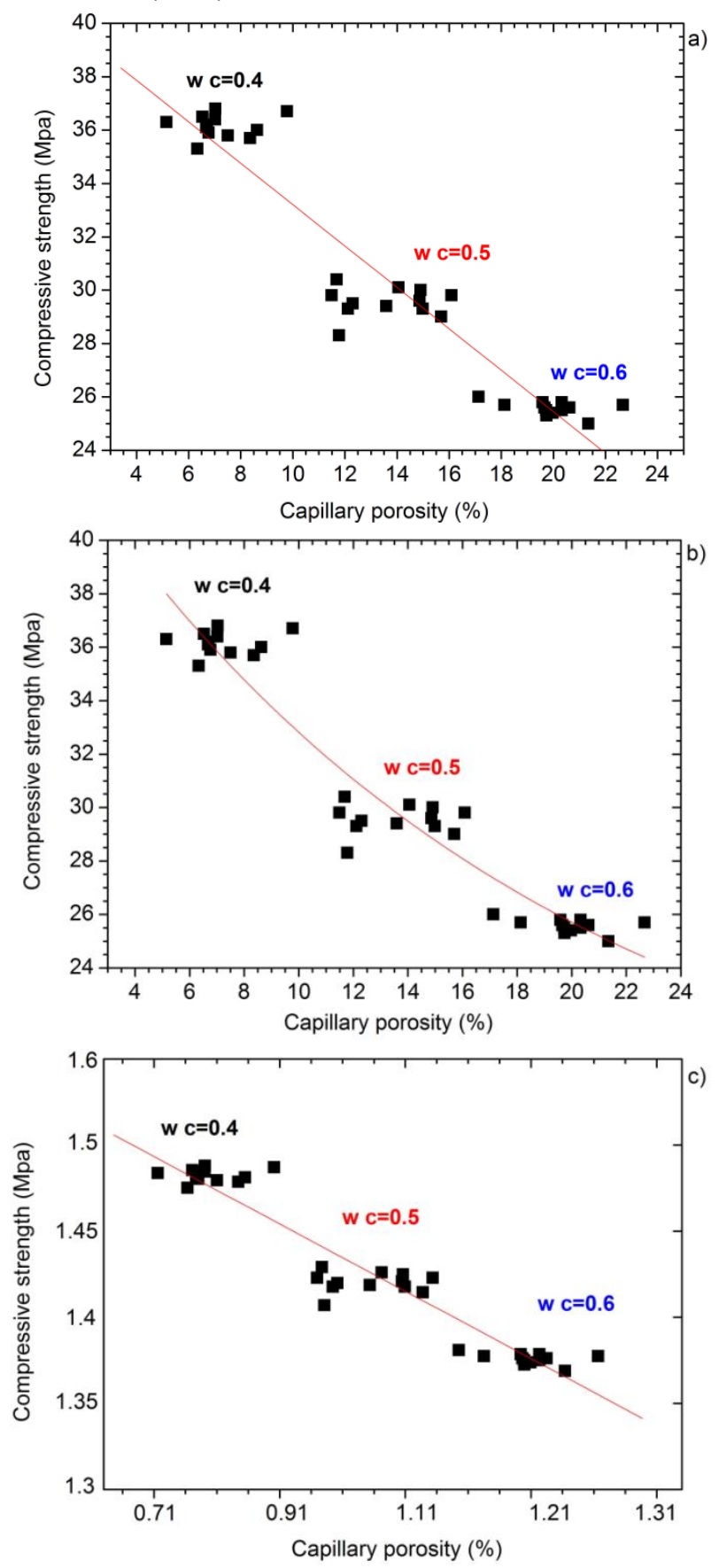


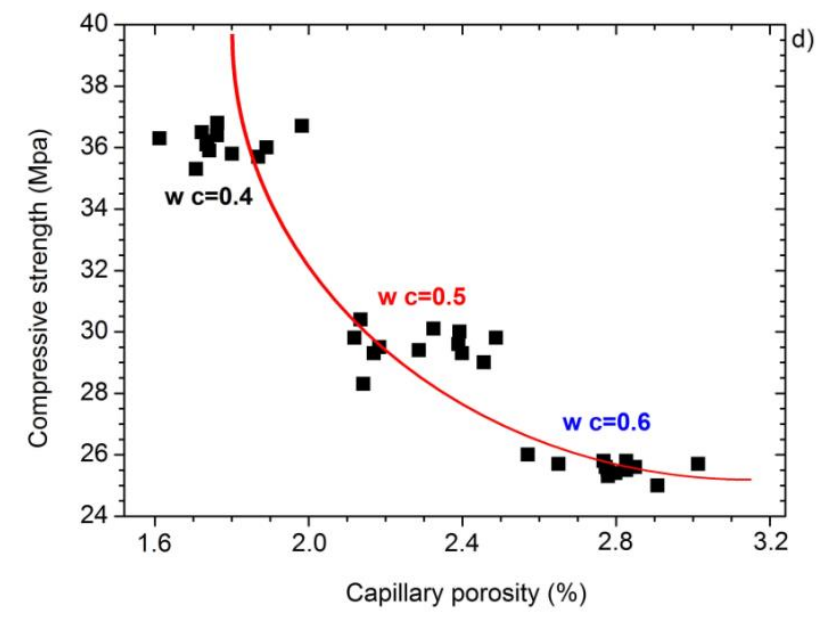

Table 4. Four statistical regressions fitted. Source: Own elaboration, 2015.

\begin{tabular}{ccc}
\hline Figs. & $\begin{array}{c}\text { Regressions } \\
\mathrm{n}=36\end{array}$ & $\begin{array}{c}\mathrm{R}^{2} \\
(\%)\end{array}$ \\
\hline $6 \mathrm{a})$ & $R_{b k}=40.96-0.77 P_{t}$ & 90 \\
$6 \mathrm{~b})$ & $R_{b k}=16.29+28.98 e^{-x / 17.8}$ & 93 \\
$6 \mathrm{c})$ & $R_{b k}=65.57\left(P_{t}\right)^{-0.30}$ & 91 \\
$6 \mathrm{~d})$ & $R_{b k}=54.35-9.49 \ln \left(P_{t}\right)$ & 91 \\
\hline
\end{tabular}

This results coincides with obtained by other authors for a concrete foamed where porosity values were determined using the Vacuum Saturation Apparatus (Kearsley \& Wainwrightb, 2002; Lian, Zhuge, \& Beecham, 2011). Nevertheless, other durability requirements from the relationship between compressive strength and percentage of effective capillary porosity can be obtained.

A value of $R_{b k_{0}}=16.29 \mathrm{Mpa}$ appears which could indicate the compressive strength for concretes with water/cement ratio and percentage of effective capillary porosity higher than 0.6 and $24 \%$ respectively in the regression based on exponential increasing function (Ryshkevitch) (Table 4). The values of 17.8 indicate the percentage of effective capillary porosity from which compressive strength $(\approx 27 \mathrm{Mpa}$ ) begins to decrease abruptly (Figure $6 \mathrm{~b}$ ). Therefore, concrete of water/cement ratio 0.6 and compressive strength values between 25 and 27 Mpa should not present the quality and durability adequate to be exposed to corrosivity categories of the atmospheres high (C4), very high (C5) and extreme (CX) in tropical coastal climates. The result could be different from the established according to DURAR net of CyTED program, as well as with the obtained from ultrasonic pulse velocity values.

Regarding to concrete with water/cement ratio 0.5 , compressive strength values between 28 and $30.5 \mathrm{Mpa}$ fall down in the percentage of effective capillary porosity range $(10 \% \leq \varepsilon<15 \%)$ where concrete quality is moderate (Figure6b).Deterioration degree very advanced due to atmospheric corrosion of steel reinforced concrete is observed in many reinforced concrete structures expose to corrosivity categories of the atmospheres high (C4), very high (C5) and extreme (CX) in tropical coastal climates of Cuba without shielding condition. Compressive strength values fall down between 28 and 30.5 Mpa (Castañeda et al., 2012).

On the other hand, for a value of percentage of effective capillary porosity (8.5\%) obtained in the regression (6), concrete with compressive strength values higher $34 \mathrm{Mpacould}$ also be obtained (Figure $6 \mathrm{~b}$ ). Concrete with percentage of effective capillary porosity value of $10 \%$ could present a compressive strength value about $33 \mathrm{Mpa}$, that is to say, very similar. Thus, a concrete with adequate quality and durability before submitting to environmental exposure conditions could be guaranteed. 


\section{Visual observation in the reinforced concrete probes}

All results obtained previously are confirmed from visual observation in the reinforced concrete probes with the same concrete and water/cement ratio exposed to corrosivity categories of the atmospheres very high (C5) and extreme (CX) in tropical coastal climates of Havana City, Cuba, during three years, at a distance from the sea of $20 \mathrm{~m}$ without shielding condition(Figure 7). Annual average values of chloride deposition rate and Sulphur compound deposition rate were $769.43 \mathrm{mg} \mathrm{m}^{-2} \mathrm{~d}^{-1}$ and $57.66 \mathrm{mg} \mathrm{m}^{-2} \mathrm{~d}^{-1}$ respectively. Therefore, the atmosphere was classified as coastal-industrial. The reinforced concrete probes elaboration was very well explained by (Castañeda, Corvo, Howland, \& Marrero, 2014).

A deterioration degree very advanced due to atmospheric corrosion of steel reinforced concrete is observed in the reinforced concrete probes with water/cement ratios 0.5 and 0.6 in both recovering thickness (Figure 7). Cracking is very noticeable principally to recovering thickness of $20 \mathrm{~mm}$. Presence of cracking in the reinforced concrete probes with water/cement ratio 0.4 was not observed.

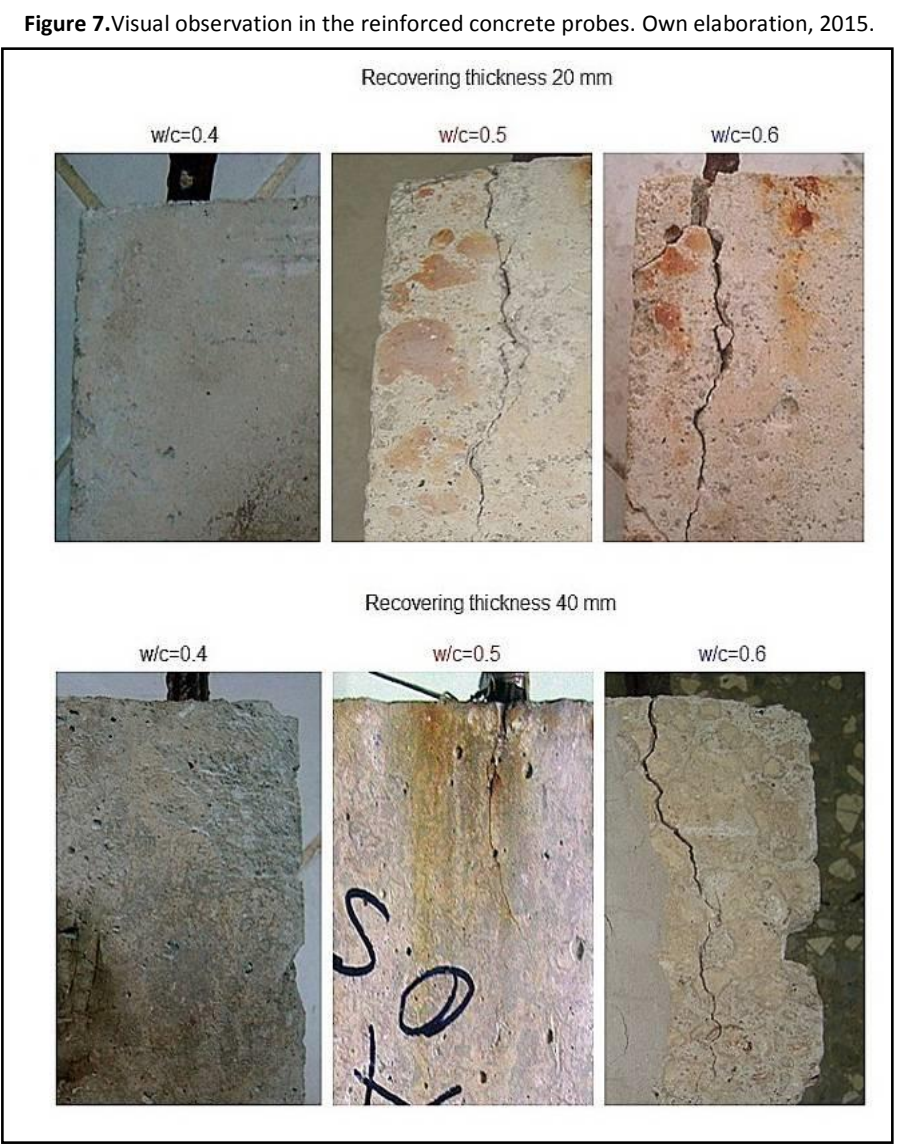

Therefore, it is confirmed that for ensure a concrete with quality and durability adequate before submitting to environmental exposure conditions in addition to having a water/cement less than or equal to 0.4 , capillary coefficient absorption values should be less than $0.0035 \mathrm{~kg} \mathrm{~m}^{-2} \mathrm{~s}^{1 / 2}$.

It is also confirmed that, for a percentage of effective capillary porosity value of $8.5 \%$, concrete with compressive strength values higher $34 \mathrm{Mpa}$ could be obtained with the purpose of guaranteeing the concrete quality assessment before building structures submitting to environmental exposure conditions. All these durability requirements are present in the new Cuban's standard: Concrete-specification.

\section{Scanning Electron Microscopy observation}

Scanning electron microscopy tests in small samples of hardened cement paste for the three water/cement ratios allowed continuing confirming the durability requirements obtained. Capillary pores formation were no appreciable in small samples of hardened cement paste in concrete with water/cement ratio 0.4. For better observation, magnification increases was necessary during the test (Figure 8 a), b) and c). 


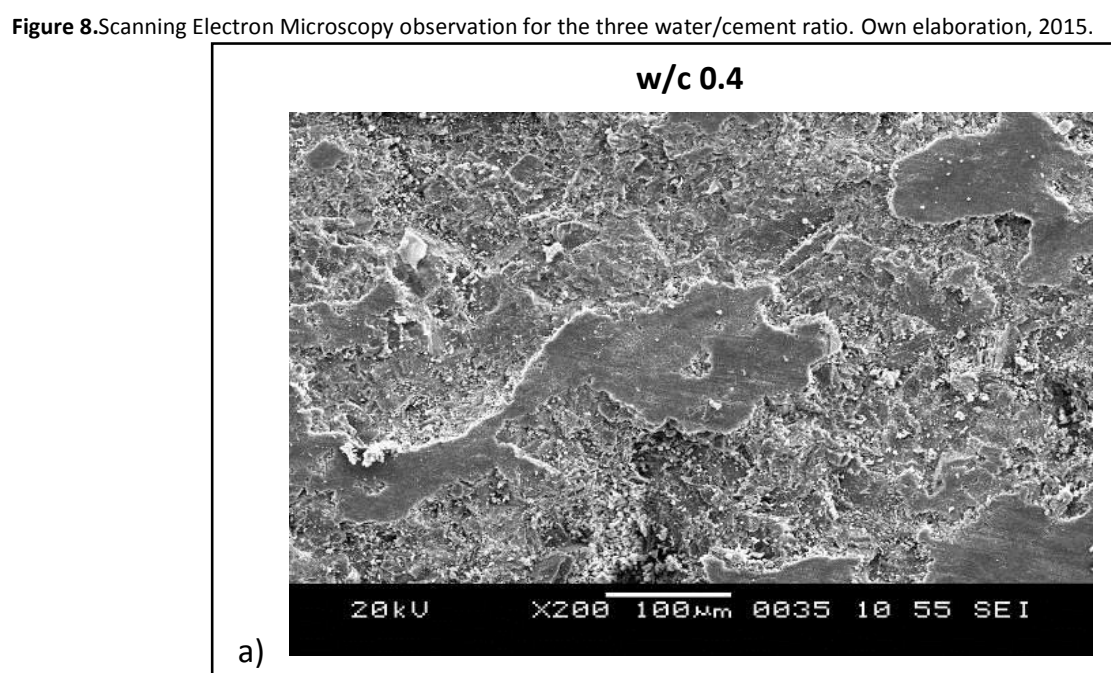

a)

\section{w/c 0.5}

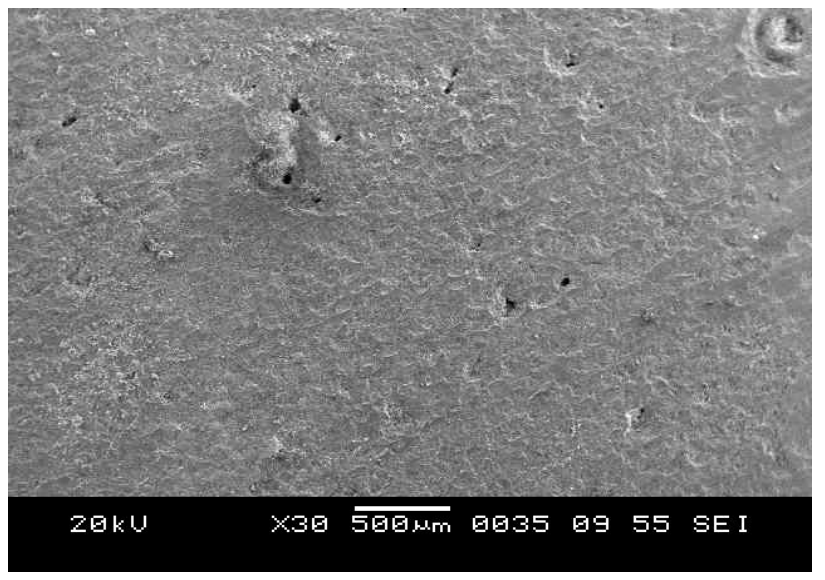

b)

$$
\text { w/c } 0.6
$$

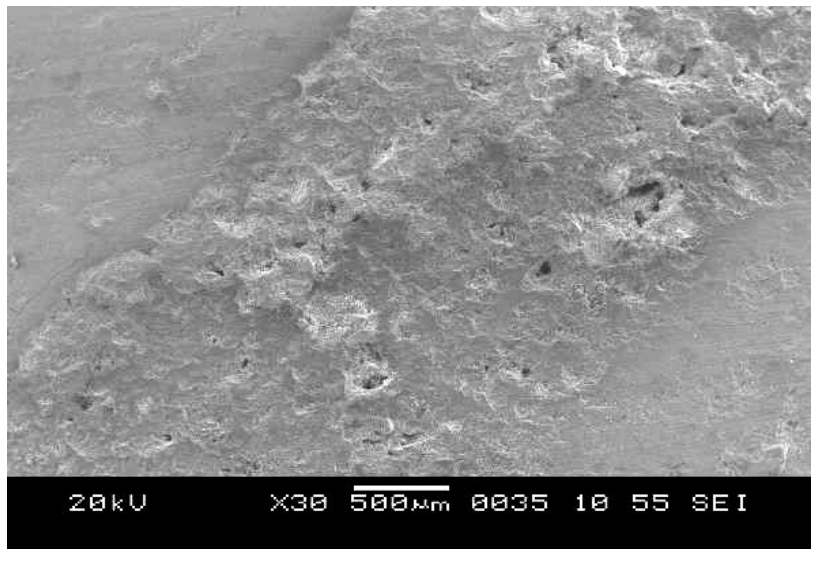

Capillary pores formed around 175 and $250 \mu \mathrm{m}$ in small samples of hardened cement in concretes with water/cement ratios 0.5 and 0.6 respectively were observed.

High capillary porosity is originated due to entire non-occurrence of the hydration reactions between chemical compounds of cement and water in the interfaces (Shuqiang \& Minhong, 2006). Therefore, high values of capillary coefficient adsorption and percentage of effective capillary porosity for the concretes of water/cement ratios 0.5 and 0.6 were obtained. 
Concrete quality assessment before building structures submitting to environmental exposure conditions were carried out where:

Ultrasonic pulse velocity and compressive strength tests by itself are not enough to concrete quality assessment. From relationship between compressive strength and percentage of effective capillary porosity, as well as, from relationship between capillary coefficient absorption and percentage of effective capillary porosity, durability requirements were obtained.

Durability requirements were:

Critical value of percentage of effective capillary porosity (8.5\%) from which capillary coefficient absorption $k$, that it to say, the permeability it increased.

Critical value of percentage of effective capillary porosity (8.5\%) where for smaller o equal values, the compressive strength guarantees a concrete quality adequate before building structures exposed to corrosivity categories of the atmospheres very high (C5) and extreme (CX) in tropical coastal climates, as well as in coastal-industrial atmosphere. Critical value of percentage of effective capillary porosity (17.8\%) from which compressive strength decreased.

Concretes before submitting to environmental exposure condition besides to having a good homogeneity and compactness due to distribution of its elements according to ultrasonic pulse velocity values, a good distribution of capillary pores interconnected in the hardened cement paste throughout the concrete mass could also be expected. Results were confirmed from visual observation.

Acebes, M. (2011). Study of the influence of microestructural parameters on the ultrasonic velocity in steel-fiber-reinforced cementitious materials. Construction and Building Materials, 25 (2), 3066-3072.

Benmeddour, F. (2012). Development of an ultrasonic experimental device to characterize concrete for structural repair. Construction and Building Materials, 37 (3), 934-942.

Bermúdez, M, A. \& Gutiérrez, P. A. (2007). Permeabilidad a los cloruros del hormigón armado situado en ambiente marino sumergido. Revista Ingeniería de Construcción, 22 (1), 15-22.

Castañeda, A., Rivero, C., \& Corvo, F. (2012). Evaluación de sistemas de protección contra la corrosión en la rehabilitación de estructuras construidas en sitios de elevada agresividad corrosiva en Cuba. Revista de la Construcción de Chile, 11 (3), 49-61.

Castañeda, A., Corvo, F., Howland, J. J., \& Pérez, T. (2013). Corrosion of steel reinforced concrete in tropical coastal atmosphere of Havana City. Revista Química Nova, 36 (2), 220-229.

Castañeda, A., Corvo, F., Howland, J. J., \& Marrero, R. (2014). Study of Atmospheric Corrosion of Reinforcement Steel in Havana, Cuba. Revista de la Construcción de Chile, 13(1), $32-40$.

Castro-Borges, P., Torres-Acosta, A., Balancán-Zapata, M., \& López-González, A. (2012). Análisis de daños por la interacción de cargas ambientales y estructurales en una subestructura marina. Revista de la Construcción de Chile, 11(3), 88-98.

Chen, X., Wu, S., \& Zhou, J. (2013). Influence of porosity on compressive and tensile strength of cement mortar. Construction and Building Materials, $40(2), 869-874$.

Fernández, A., Martín, A. R., Rey, G., Pares, R., García, L., Lago, A., \& Denis, E. (2005). Diagnóstico de corrosión en obras de hormigón armado con más de 70 años de edad. In: A. Ayala (Presidencia), Patología de las Estructuras. Simposio llevado a Cabo en el VII Congreso Latinoamericano de Patología de la Construcción CONPAT 2005, Asunción, Paraguay.

Fagerlund, G. (1986). On the capillarity of Concrete. Nordic Concrete Research, Oslo, 11(6), 12-25.

International Standard ISO 9223. (2012). Corrosion of metals and alloys - Corrosivity of atmospheres - Classification determination and estimation. Second edition 2012-02-01. Reference number ISO 9223:2012 (E).

Kearsley, E. P., \& Wainwrightb, J. (2002).The effect of porosity on the strength of foamed concrete. Cement and Concrete Research, 32(4), 233-239.

Lian, C., Zhuge, Y., \& Beecham, S. (2011). The relationship between porosity and strength for porous concrete. Construction and Building Materials, 25(2), 4294-4298.

Medeiros, M., \& Helene, P. (2009). Surface treatment of reinforced concrete in marine environment: Influence on chloride diffusion coefficient and capillary water absorption. Construction and Building Materials, 23(2), 1476-1484.

NC ISO-1920-3 (2010). Ensayos de hormigón. Parte 3: Elaboración y curado de probetas para ensayos. Norma Cubana. Preparation and curing of test specimens. Edited in November 2015. 
NC 724 (2015). Ensayos del hormigón - resistencia del hormigón en estado endurecido (ISO 1920-4: 2005, MOD). Norma Cubana. Testing of concrete - Strength of hardened concrete. Edited in October 2015

Norma Cubana NC 231 (2002). Determinación, interpretación y aplicación de la velocidad de pulso ultrasónico en el hormigón. Determination, interpretation and application of the ultrasonic pulse velocity in concrete. Edited in November 2002.

Ozbek, A, S. (2013). Investigating porous concrete with improved strength: Testing at different scales. Construction and Building Materials, 41(4), 480490.

Petro, J, T., \& Kim, J. (2012). Detection of delamination in concrete using ultrasonic pulse velocity test. Construction and Building Materials, 26(3), 574-582.

Shariq, M., Prasad, J., \& Masood, A. (2013). Studies in ultrasonic pulse velocity of concrete containing GGBFS. Construction and Building Materials, 40(2), 944-950.

Shuqiang, Z., \& Minhong, Z. (2006). Hydration of cement and pore structure of concrete cured in tropical environment. Cement and Concrete Research, 36(4), 1947- 1953.

Trocónis, O., \& Duracon Collaboration (2006). Durability of concrete structures: DURACON, an iberoamerican project. Preliminary results. Building and Environment, 41(7), 952-962.

Trocónis, O., Sánchez, M., Millano, V., Fernández, R., Partidas, E, A., Andrade, C., Martínez, I., Castellote, M., Barboza, M., Irassar, F.; Montenegro, J. C., Vera, R., Carvajal, A. M., Gutiérrez, R. M. de, Maldonado, J., Guerrero, C., Saborio-Leiva, E., Villalobos, A. C., Tres-Calvo, G., Torres-Acosta, A. A., Pérez-Quiroz, J. T., Martínez-Madrid, M., Almeraya, F., Castro-Borges, P., Moreno, E. I., Pérez-López, T., Salta, M., Melo, A. P. de, Rodríguez, G.; Pedrón, M., \& Derrégibus, M. (2007). Effect of the marine environment on reinforced concrete durability in Iberoamerican countries: DURACON project/CYTED. Corrosión Science, 49(7), 2832-2843.

Trocónis, O. (1997). Manual de inspección, evaluación y diagnóstico de corrosión en estructuras de hormigón armado. Río de Janeiro, Brasil: CYTED, Red Temática XV. B. Durabilidad de la armadura. 